\title{
Proteome-wide screening for the analysis of protein targeting of Chlamydia pneumoniae in endoplasmic reticulum of host cells and their possible implication in lung cancer development
}

\author{
Yanyan LI ${ }^{1}$; Shahanavaj KHAN ${ }^{2,3,4, *}$; Anis Ahmad CHAUdHARY ${ }^{5}$; Hassan Ahmed RUDAYNI ${ }^{5}$; Abdul MALIK ${ }^{2}$; \\ AsHWAG SHAMI ${ }^{6 * *}$ \\ ${ }^{1}$ Department of Oncology, Zhengzhou Central Hospital Affiliated to Zhengzhou University, Zhengzhou, 450007, China \\ 2 Department of Pharmaceutics, College of Pharmacy, King Saud University, Riyadh, 11451, Saudi Arabia \\ ${ }^{3}$ Department of Biosciences, Shri Ram Group of College (SRGC), Muzaffarnagar, 251001, India \\ ${ }^{4}$ Department of Health Sciences, Novel Global Community Educational Foundation, Sydney, Australia \\ ${ }^{5}$ Department of Biology, College of Science, Imam Mohammad Ibn Saud Islamic University (IMSUI), Riyadh, 11623, Saudi Arabia \\ ${ }^{6}$ Department of Biology, College of Sciences, Princess Nourah bint Abdulrahman University, Riyadh, 11617, Saudi Arabia
}

Key words: Bacterial infection, C. pneumoniae, Proteomes, ER, Lung cancer

\begin{abstract}
Available reports have confirmed a link between bacterial infection and the progression of different types of cancers, including colon, lungs, and prostate cancer. Here we report the Chlamydia pneumonia proteins targeting in endoplasmic reticulum (ER) using in-silico approaches and their possible role in lung cancer etiology. We predicted 48 proteins that target human ER, which may be associated with protein folding and protein-protein interactions during infection. The results showed C. pneumoniae proteins targeting human ER and their implications in lung cancer growth. These targeted proteins may be involved in competitive interactions between host and bacterial proteins, which may change the usual pathway functions and trigger the development of lung cancer. Moreover, C. pneumoniae unfolded protein accumulation in the human ER possibly induces ER stress, consequently activating the unfolded protein response (UPR), and providing a favorable microenvironment for cancer growth. The current study showed the C. pneumoniae protein targeting in ER of host cell and their implication in lung cancer growth. These results may help researchers better manage lung cancer and establish a molecular mechanism for C. pneumoniae lung cancer association.
\end{abstract}

\section{List of abbreviations}

ER: $\quad$ Endoplasmic reticulum

IL: Interleukin

MW: molecular weight

kDa: kiloDalton

pI: $\quad$ isoelectric point

UPR: unfolded protein response

\section{Introduction}

Lung cancer is one of the very common cancer, with 1.8 million (approximately $13 \%$ of the total cancer) new cases estimated

\footnotetext{
*Address correspondence to: Shahanavaj Khan, sdkhan@ksu.edu.sa; Ashwag Shami, Ayshami@pnu.edu.sa

Received: 13 March 2021; Accepted: 17 May 2021
}

globally in 2012 (Ferlay et al., 2015). The most common cancer is lung carcinoma and leading cause of death, after breast cancer in female and prostate cancer in men (Bray et al., 2018). The association of infection of bacteria with the progression of different types of cancer has confirmed in various studies (Arthur et al., 2012; Khan, 2015; Magat et al., 2020). The Gram-negative microbe Chlamydia pneumoniae is an intracellular obligate bacterium. C. pneumoniae is transmitted due to acute respiratory infection and potentially associated with lung disease including bronchitis, asthma, atherosclerosis, and high risk of lung cancer however, the causal pathogenetic mechanisms are not well understood. The infection of C. pneumoniae has been reported to alter several pathways of infected host cell including calcium-mediated nuclear factor- $\mathrm{kB}$ (NF- $\mathrm{kB}$ ) pathway, apoptosis, necrosis etc (Chaturvedi et al., 2010; Littman et al., 2005; Wahl et al., 2003). NF-kB has crucial role in proliferation, inflammation, and regulation of apoptosis. Alteration in program cell death due to NF- $\mathrm{kB}$ pathway enigmatically associated with cancer 
(Wahl et al., 2003). Inflammation may be connected with carcinogenic process due to chronic infection of bacteria in human (Littman et al., 2005). The lungs of the smoker may be more susceptible for the localization of C. pneumoniae (Von Hertzen, 1998). The radicals of superoxide oxygen, tumor necrosis factor, IL- 8 and IL- $1 \beta$ are generated by induced monocytes. The inflammatory factors may trigger the process of carcinogenesis in lung cells (Koyi et al., 1999).

C. pneumoniae contained the capability to interfering with the host cell's apoptotic apparatus. Alteration in the apoptosis has been related to survival scheme of intracellular C. pneumoniae. Many reports of C. pneumoniae infection have been demonstrated to inhibit host cell apoptosis (Airenne et al., 2002; Fischer et al., 2001; Wahl et al., 2003). However, some contradictory study has shown the proapoptotic activities of $C P$ during the infection (Sessa et al., 2009). Members of the inhibitor of apoptosis protein family are important factors that regulate apoptotic cell death. The infection of $C$. pneumoniae showed the induction of the expression of mRNA and protein of cellular inhibitor of apoptosis 2 (c-IAP2) in human cell line Mono Mac 6 that may help to intracellular survival of the bacterium (Wahl et al., 2003). The carcinogenic process of lung cancer due to the infection of C. pneumoniae is still infancy stage.

Cancer is a serious problem around the world and arises due to various factors including infection, mutations, smoking and disturbance in homeostasis of various biological process. Endoplasmic reticulum (ER) is the important subcellular organelle of eukaryotes which transfers various proteins to their subcellular location or on surface of the cell (Braakman and Bulleid, 2011). ER has various molecular chaperones which involved in protein synthesis, protein folding and maturation. Several biological processes are controlled by the normal functioning of ER. Interestingly, there are several connections to activation of ER stress response constitutes a cellular process that can be triggered by a great variety of pathological human conditions such as Alzheimer's disease and cancer. Different conditions including inflammatory bowel disease, diabetes and various types of cancers are related to the activation of the ER stress response pathway. ER stress is induced in numerous pathological and physiological conditions through accretion of misfolded proteins in the lumen of ER.

In the current work, we predicted the C. pneumoniae protein targeting in the ER of host cell and their possible involvement in the growth of lung cancer. We utilized the bioinformatics approach to decipher the possible localization of whole protein sequences of C. pneumoniae in ER of host cells. Furthermore, we predicted the possible role of molecular weight and isoelectric point of ER targeted proteins in protein targeting and growth of lung cancer. We expect that our results might be very helpful, valuable to provide right direction to experimental research in wet lab experiments.

\section{Materials and Methods}

\section{Selection of database}

Various databases were served in order to obtain maximum proteins sequences of $C$. pneumoniae. In the current study we were served the different database such as NCBI,
Uniprot and EMBL to retrieve the complete proteome of C. pneumoniae.

\section{C. pneumoniae proteome retrieval}

The bacterium C. pneumoniae was infecting the host as obligate intracellular bacteria and act as possible factor in the growth of lung cancer (Hua-Feng et al., 2015; Xiong et al., 2019). Six isolates (CWL029, AR39, J138, B21, TW-183, LPCoLN) of bacteria were available in Uniprot database with huge information of protein sequences (Kalman et al., 1999; Myers et al., 2009; Read et al., 2000; Shirai et al., 2000). The whole protein sequences of bacteria TW-183 isolate were retrieved from Uniprot database. These protein sequences were utilized to decipher the ER targeted proteins using bioinformatics approach.

Deciphering the endoplasmic reticulum targeting proteins of C. pneumoniae and their role in lung cancer

Online available bioinformatics predictor Hum-mPLoc 2.0 was used in current study to decipher the C. pneumoniae proteins targeting in ER of human cells. This predictor has predicted subcellular localization of proteins in various organisms. (Shen and Chou, 2009). This predictor has predicted subcellular localization of proteins in various organisms. All proteins sequences of TW-183 isolate of C. pneumoniae were used to predict the protein targeting in host Endoplasmic Reticulum. Hum-mPLoc 2.0 was deciphered the protein targeting in various sub cellular organelles such as endoplasmic reticulum, cytoplasm, mitochondrion, nucleus, centriole, cytoskeleton, endosome, extracell, golgi apparatus, lysosome etc. The predictor has used sequential evolution information and functional domain information using ensemble classifier. The protocol of prediction showed in general scheme (Fig. 1).

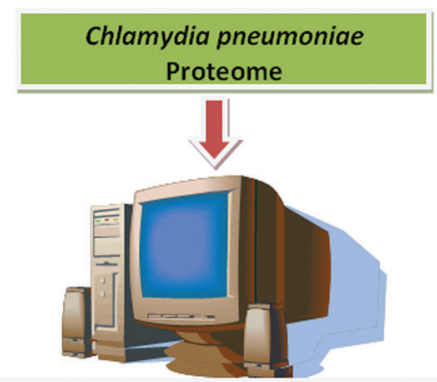

In silico Analysis of $C$. pneumoniae protein targeting in subcellular organelles by Hum-mPLoc

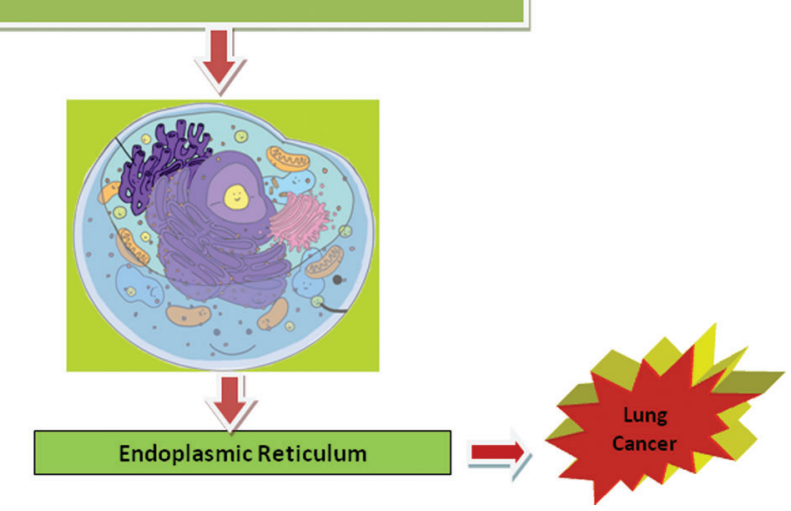

FIGURE 1. Illustration showed the plan of prediction strategies. 
Decipher the possible relation of particular molecular weight of C. pneumoniae proteins in endoplasmic reticulum targeting and their role in lungs cancer

ExPASy online bioinformatics predictor compute $\mathrm{pI} / \mathrm{Mw}$ tool was used to decipher the molecular weight in whole protein sequences of TW-183 bacteria. This tool was used to analyse the various characters of proteins in proteomics research. The tool was worked on experimentally available information of particular amino acid and provided accurate results.

Decipher the possible relation of particular isoelectric point of C. pneumoniae proteins in endoplasmic reticulum targeting and their role in lung cancer

Similarly, ExPASy online bioinformatics predictor compute $\mathrm{pI} / \mathrm{Mw}$ tool was utilized to decipher the isoelectric point (pI) in whole protein sequences of TW-183 bacteria.

\section{Results}

Selection of database and retrieve of proteome

In the present work, we were selected the Uniprot database to retrieving the protein sequences of $C$. pneumoniae. Uniprot database was contained information of most of the bacterium and considered a reliable source for bioinformatic study.

To retrieve the proteome of $C$. pneumonia

TW-183 isolate of C. pneumoniae was selected for the retrieving of whole protein sequences of bacterium due to their large size proteome. The proteome was contained maximum number of protein sequences.

Decipher the endoplasmic reticulum targeting proteins of C. pneumoniae and their role in lungs cancer

The results of Hum-mPLoc 2.0 were showed that only 48 proteins of TW-183 isolate of C. Pneumonia targeted in ER of host cells. The descriptions of proteins such as Accession number, possible functions, and number of amino acids are shown in Tab. 1.

The normal functions of host cells may alter trough different strategies due to the protein-protein interaction in the lumen of ER as existences of C. Pneumoniae proteins. ER plays very important role in protein folding and formation of active proteins/enzymes.

Decipher the possible relation of particular molecular weight of C. pneumoniae proteins in endoplasmic reticulum targeting and their role in lungs cancer

Whole protein sequences of $C$. pneumoniae were used to calculate the theoretical molecular weight (MW) using compute $\mathrm{pI} / \mathrm{Mw}$ tool (https://web.expasy.org/compute_pi/). This tool is highly useful to decipher the MW and theoretical pI value in unknown protein sequence. The relations of specific range of molecular weight of ER target proteins and whole proteins of TW-183 isolate of C. pneumoniae were demonstrated in Figs. $2 \mathrm{~A}$ and $2 \mathrm{~B}$.

The results of our current study were clearly demonstrated that the increases in molecular weight consistently decreased the targeting of proteins in ER of host cells. The proteins contain lowest range of molecular weight $(0-20 \mathrm{kDa}$ were showed high potential to target in ER of host cell while the protein having highest molecular (>80 kDa) weight were showed very little potential to target in ER of host cells.

Decipher the possible relation of particular isoelectric point of C. pneumoniae proteins in endoplasmic reticulum targeting and their role in lung cancer

Similarly, the values of isoelectric point (pI) in whole proteins sequences of TW-183 isolate of $C$. pneumoniae were deciphered using online tool compute $\mathrm{pI} / \mathrm{Mw}$. The relations of specific range of $\mathrm{pI}$ values of ER target proteins and whole proteins of TW-183 isolate of C. pneumoniae were demonstrated in Figs. 3A and 3B.

The previous report demonstrated that pathogen protein translocation is supported through a neutral isoelectric point (pI) between 6.0 to 8.4 . Nevertheless, for proteins $>50 \mathrm{kDa}$ in size, pI alone does not clarify their localisation (Smigielski et al., 2019). The results were showed that the value of isoelectric point (pI) was not showing any constant pattern for protein targeting in ER of host cells (Fig. 3A and $3 \mathrm{~B})$. It was observed that the pI value 9-10 have the high potential (24 Proteins) to target in ER of host cells.

\section{Discussion}

Although wet lab research and experiments for analysing protein targeting signals can provide comprehensible evidence and distinguish between maintenance and return signals but performing wet lab research and experiments are generally more time-taking and costly. Therefore, in-silico computational research is recognized as an alternative approach that presents informative, valuable, and useful direction to experimental research. Cell is considered the small unit of life, which holds numerous molecules including proteins and enzymes. Various subcellular locations generally called cell organelles contain different proteins which have the important functions for the cell's survival'. ER is a main subcellular organelle in the cells of eukaryotes. Approximate one-third the proteins are transported to various subcellular locations to the cells through the ER (Hetz et al., 2015). It is involved in regulation of various essential biological processes including protein folding, post-translational modification, cell metabolism and protein synthesis (Schwarz and Blower, 2016).

In our current study 48 different proteins were predicted to be targeted to the ER of human cells from the entire proteome of C. pneumoniae. These targeted proteins of C. pneumoniae may alter the different functions of human cell during the course of infection. This study has showed that ER of infected epithelial cells mostly contained chlamydial major outer membrane protein (MOMP), lipopolysaccharide (LPS) and the inclusion membrane protein A (IncA) (Giles and Wyrick, 2008). The in-silico to decipher the protein targeting into the human cell is very essential to discover the growth of cancer, particularly when the progression of cancer is related to the bacterial intracellular infection. Various studies have showed that many targeted proteins of bacteria in different subcellular organelles of host cell (including mitochondria, Golgi complex, cytoplasm, and nucleus) exert adverse effect and act as the etiological factors 
TABLE 1

The data in the table showed the details information of $C$. pneumoniae proteins, which targeted in the endoplasmic reticulum of host cell

\begin{tabular}{|c|c|c|c|c|c|c|c|}
\hline $\begin{array}{l}\text { S. } \\
\text { No. }\end{array}$ & $\begin{array}{l}\text { Accession } \\
\text { No. }\end{array}$ & Proteins/Enzymes name & $\begin{array}{l}\text { No. of } \\
\text { Amino } \\
\text { acid }\end{array}$ & Function in bacteria & $\begin{array}{l}\text { pI } \\
\text { Values }\end{array}$ & $\begin{array}{l}\text { Mol. } \\
\text { Wt. }\end{array}$ & $\begin{array}{l}\text { Localization } \\
\text { by Hum- } \\
\text { mPLoc } 2.0 \\
\end{array}$ \\
\hline 1. & Q9Z7Y4 & $\begin{array}{l}\text { 1-acyl-sn-glycerol-3-phosphate } \\
\text { acyltransferase, putative (Glycerol-3-P } \\
\text { Acyltransferase) }\end{array}$ & 212 & $\begin{array}{l}\text { Transferase activity, transferring } \\
\text { acyl groups }\end{array}$ & 9.68 & 24,449 & $\begin{array}{l}\text { Endoplasmic } \\
\text { reticulum }\end{array}$ \\
\hline 2. & Q9Z943 & Uncharacterized protein & 146 & nuclease activity & 4.88 & 16,716 & $\begin{array}{l}\text { Endoplasmic } \\
\text { reticulum }\end{array}$ \\
\hline 3. & Q9Z8D4 & Uncharacterized protein & 161 & Unknown & 4.96 & 18,609 & $\begin{array}{l}\text { Endoplasmic } \\
\text { reticulum }\end{array}$ \\
\hline 4. & Q9Z6V8 & $\begin{array}{l}\text { Glycogen synthase (EC 2.4.1.21) (Starch } \\
\text { [bacterial glycogen] synthase) }\end{array}$ & 476 & $\begin{array}{l}\text { Glycosyltransferase, Transferase, } \\
\text { Glycogen biosynthesis }\end{array}$ & 4.97 & 53,146 & $\begin{array}{l}\text { Endoplasmic } \\
\text { reticulum }\end{array}$ \\
\hline 5. & Q9Z778 & $\begin{array}{l}\text { Secretion protein (Type III secretion } \\
\text { protein SctJ) (Yop proteins translocation } \\
\text { lipoprotein J) }\end{array}$ & 335 & protein secretion & 5.44 & 36,245 & $\begin{array}{l}\text { Endoplasmic } \\
\text { reticulum }\end{array}$ \\
\hline 6. & Q9Z8P4 & $\begin{array}{l}\text { Cyclic nucleotide-binding protein } \\
\text { (cAMP-Dependent Protein Kinase } \\
\text { Regulatory Subunit) }\end{array}$ & 137 & kinase activity & 5.52 & 15,555 & $\begin{array}{l}\text { Endoplasmic } \\
\text { reticulum }\end{array}$ \\
\hline 7. & Q9Z7G4 & $\begin{array}{l}\text { Transcription elongation factor GreA } \\
\text { (Transcript cleavage factor GreA) }\end{array}$ & 722 & $\begin{array}{l}\text { Transcription, Transcription } \\
\text { regulation }\end{array}$ & 5.52 & 82,642 & $\begin{array}{l}\text { Endoplasmic } \\
\text { reticulum }\end{array}$ \\
\hline 8. & Q7VPT1 & Anti-sigma factor antagonist & 115 & regulation of transcription & 5.77 & 12,860 & $\begin{array}{l}\text { Endoplasmic } \\
\text { reticulum }\end{array}$ \\
\hline 9. & Q9Z8A8 & $\begin{array}{l}\text { Phospholipase D family protein } \\
\text { (Phospholipase D superfamily) (Putative } \\
\text { phospholipase D) }\end{array}$ & 476 & catalytic activity & 5.99 & 54,470 & $\begin{array}{l}\text { Endoplasmic } \\
\text { reticulum }\end{array}$ \\
\hline 10. & Q9Z8U6 & $\begin{array}{l}\text { Glucose-6-phosphate 1-dehydrogenase } \\
\text { (G6PD) }\end{array}$ & 512 & $\begin{array}{l}\text { Oxidoreductase, glucose-6- } \\
\text { phosphate dehydrogenase activity }\end{array}$ & 6.25 & 58,740 & $\begin{array}{l}\text { Endoplasmic } \\
\text { reticulum }\end{array}$ \\
\hline 11. & Q9Z6U9 & $\begin{array}{l}\text { Axial Filament Protein (Cytosolic axial } \\
\text { filament protein cafA and ribonuclease } \\
\text { E) (Ribonuclease G) }\end{array}$ & 515 & ribonuclease activity & 6.32 & 59,551 & $\begin{array}{l}\text { Endoplasmic } \\
\text { reticulum }\end{array}$ \\
\hline 12. & Q9Z779 & $\begin{array}{l}\text { Putative uncharacterized protein } \\
\text { CPn } 0827 \text { Homolog (Uncharacterized } \\
\text { protein) }\end{array}$ & 277 & Unknown & 8.18 & 31,821 & $\begin{array}{l}\text { Endoplasmic } \\
\text { reticulum }\end{array}$ \\
\hline 13. & Q9Z7C1 & $\begin{array}{l}\text { ExbB (Macromolecule transporter) } \\
\text { (MotA/TolQ/ExbB proton channel } \\
\text { family protein) }\end{array}$ & 232 & protein transporter activity & 8.48 & 25,575 & $\begin{array}{l}\text { Endoplasmic } \\
\text { reticulum }\end{array}$ \\
\hline 14. & Q9Z809 & $\begin{array}{l}\text { Probable metal transport system } \\
\text { membrane protein }\end{array}$ & 293 & Transport, ATPase activity & 8.72 & 32,243 & $\begin{array}{l}\text { Endoplasmic } \\
\text { reticulum }\end{array}$ \\
\hline 15. & Q7VPR2 & $\mathrm{ABC}$ transporter & 591 & transport & 8.82 & 66,061 & $\begin{array}{l}\text { Endoplasmic } \\
\text { reticulum }\end{array}$ \\
\hline 16. & Q9Z978 & $\begin{array}{l}\text { Cytochrome D ubiquinol oxidase, } \\
\text { subunit II }\end{array}$ & 344 & oxidation reduction process & 8.85 & 38,174 & $\begin{array}{l}\text { Endoplasmic } \\
\text { reticulum }\end{array}$ \\
\hline 17. & Q9Z8W7 & Uncharacterized protein & 228 & Unknown & 8.87 & 25,657 & $\begin{array}{l}\text { Endoplasmic } \\
\text { reticulum }\end{array}$ \\
\hline 18. & Q9Z6P9 & UPF0056 membrane protein & 202 & Unknown & 8.95 & 22,652 & $\begin{array}{l}\text { Endoplasmic } \\
\text { reticulum }\end{array}$ \\
\hline 19. & Q9Z8J7 & $\begin{array}{l}\text { Probable metal transport system } \\
\text { membrane protein }\end{array}$ & 324 & $\begin{array}{l}\text { Transport, ATPase activity, } \\
\text { coupled to transmembrane } \\
\text { movement of substances Source: } \\
\text { InterPro }\end{array}$ & 9.07 & 35,249 & $\begin{array}{l}\text { Endoplasmic } \\
\text { reticulum }\end{array}$ \\
\hline 20. & Q9Z816 & $\begin{array}{l}\text { Alanine/glycine transporter protein (D- } \\
\text { Ala/Gly Permease) (D-Ala/Gly } \\
\text { permease) }\end{array}$ & 449 & alanine: sodium symporter activity & 9.12 & 49,481 & $\begin{array}{l}\text { Endoplasmic } \\
\text { reticulum }\end{array}$ \\
\hline
\end{tabular}


Table 1 (continued).

\begin{tabular}{|c|c|c|c|c|c|c|c|}
\hline $\begin{array}{l}\text { S. } \\
\text { No. }\end{array}$ & $\begin{array}{l}\text { Accession } \\
\text { No. }\end{array}$ & Proteins/Enzymes name & $\begin{array}{l}\text { No. of } \\
\text { Amino } \\
\text { acid }\end{array}$ & Function in bacteria & $\begin{array}{l}\text { pI } \\
\text { Values }\end{array}$ & $\begin{array}{l}\text { Mol. } \\
\text { Wt. }\end{array}$ & $\begin{array}{l}\text { Localization } \\
\text { by Hum- } \\
\text { mPLoc } 2.0\end{array}$ \\
\hline 21. & Q9Z7U0 & $\begin{array}{l}\text { ADP,ATP carrier protein } 2 \text { (ADP/ATP } \\
\text { translocase } 2)\end{array}$ & 540 & $\begin{array}{l}\text { Transport, ATP:ADP antiporter } \\
\text { activity }\end{array}$ & 9.15 & 60,050 & $\begin{array}{l}\text { Endoplasmic } \\
\text { reticulum }\end{array}$ \\
\hline 22. & Q9Z6V2 & Uncharacterized protein & 450 & Unknown & 9.17 & 51,759 & $\begin{array}{l}\text { Endoplasmic } \\
\text { reticulum }\end{array}$ \\
\hline 23. & Q7VPV0 & Succinate dehydrogenase subunit $\mathrm{C}$ & 297 & Unknown & 9.25 & 33,328 & $\begin{array}{l}\text { Endoplasmic } \\
\text { reticulum }\end{array}$ \\
\hline 24. & Q9Z739 & $\begin{array}{l}\text { Rod Shape Protein (Rod shape protein) } \\
\text { (Stage V sporulation protein E) }\end{array}$ & 415 & cell cycle & 9.32 & 46,663 & $\begin{array}{l}\text { Endoplasmic } \\
\text { reticulum }\end{array}$ \\
\hline 25. & Q7VPQ7 & Uncharacterized protein & 61 & Unknown & 9.43 & 7,085 & $\begin{array}{l}\text { Endoplasmic } \\
\text { reticulum }\end{array}$ \\
\hline 26. & Q7VPV8 & Uncharacterized protein & 831 & Unknown & 9.43 & 7,085 & $\begin{array}{l}\text { Endoplasmic } \\
\text { reticulum }\end{array}$ \\
\hline 27. & Q9K1X8 & Uncharacterized protein & 232 & Unknown & 9.48 & 26,313 & $\begin{array}{l}\text { Endoplasmic } \\
\text { reticulum }\end{array}$ \\
\hline 28. & Q7VQ03 & Uncharacterized protein & 53 & Unknown & 9.52 & 6,188 & $\begin{array}{l}\text { Endoplasmic } \\
\text { reticulum }\end{array}$ \\
\hline 29. & Q9Z8J2 & $\begin{array}{l}\text { ADP,ATP carrier protein } 1 \text { (ADP/ATP } \\
\text { translocase 1) }\end{array}$ & 515 & $\begin{array}{l}\text { Transport, ATP:ADP antiporter } \\
\text { activity }\end{array}$ & 9.52 & 57,197 & $\begin{array}{l}\text { Endoplasmic } \\
\text { reticulum }\end{array}$ \\
\hline 30. & Q9Z7D9 & Uncharacterized protein & 98 & Unknown & 9.57 & 11,577 & $\begin{array}{l}\text { Endoplasmic } \\
\text { reticulum }\end{array}$ \\
\hline 31. & Q9Z767 & $\begin{array}{l}\text { Phosphatidylserine decarboxylase } \\
\text { proenzyme }\end{array}$ & 301 & $\begin{array}{l}\text { Decarboxylase, Lyase, Lipid } \\
\text { biosynthesis }\end{array}$ & 9.59 & 34,827 & $\begin{array}{l}\text { Endoplasmic } \\
\text { reticulum }\end{array}$ \\
\hline 32. & Q9Z782 & $\begin{array}{l}\text { Translocation protein S (Type III } \\
\text { secretion inner membrane protein SctS) } \\
\text { (Yop proteins translocation protein S) }\end{array}$ & 95 & protein secretion & 9.6 & 10,664 & $\begin{array}{l}\text { Endoplasmic } \\
\text { reticulum }\end{array}$ \\
\hline 33. & Q9Z6Z3 & Uncharacterized protein & 62 & Unknown & 9.66 & 7,465 & $\begin{array}{l}\text { Endoplasmic } \\
\text { reticulum }\end{array}$ \\
\hline 34. & Q9Z6Y5 & $\begin{array}{l}\text { 2-acylglycerophospho-ethanolamine } \\
\text { acyl transferase/acyl carrier }\end{array}$ & 253 & transferase activity & 9.67 & 29,519 & $\begin{array}{l}\text { Endoplasmic } \\
\text { reticulum }\end{array}$ \\
\hline 35. & Q9Z9D4 & Uncharacterized protein & 66 & Unknown & 9.73 & 7,880 & $\begin{array}{l}\text { Endoplasmic } \\
\text { reticulum }\end{array}$ \\
\hline 36. & Q7VPQ0 & Uncharacterized protein & 60 & Unknown & 9.74 & 7,306 & $\begin{array}{l}\text { Endoplasmic } \\
\text { reticulum }\end{array}$ \\
\hline 37. & Q9Z817 & $\begin{array}{l}\text { Lipoprotein signal peptidase } \\
\text { (Prolipoprotein signal peptidase) }\end{array}$ & 168 & $\begin{array}{l}\text { Aspartyl protease, Hydrolase, } \\
\text { Protease }\end{array}$ & 9.74 & 19,365 & $\begin{array}{l}\text { Endoplasmic } \\
\text { reticulum }\end{array}$ \\
\hline 38. & Q9Z7S5 & Protein translocase subunit $\mathrm{SecY}$ & 457 & $\begin{array}{l}\text { Protein transport, Translocation, } \\
\text { Transport }\end{array}$ & 9.95 & 50,286 & $\begin{array}{l}\text { Endoplasmic } \\
\text { reticulum }\end{array}$ \\
\hline 39. & Q9Z8M6 & Uncharacterized protein & 151 & Unknown & 10.36 & 17,315 & $\begin{array}{l}\text { Endoplasmic } \\
\text { reticulum }\end{array}$ \\
\hline 40. & Q7VQ15 & Uncharacterized protein & 56 & Unknown & 10.51 & 6,658 & $\begin{array}{l}\text { Endoplasmic } \\
\text { reticulum }\end{array}$ \\
\hline 41. & Q9Z8N1 & Glycogen phosphorylase & 824 & $\begin{array}{l}\text { Glycosyltransferase, Transferase, } \\
\text { glycogen phosphorylase activity }\end{array}$ & 5.83 & 94,517 & $\begin{array}{l}\text { Endoplasmic } \\
\text { reticulum }\end{array}$ \\
\hline 42. & Q7VPU0 & Uncharacterized protein & 65 & Unknown & 8.8 & 7,382 & $\begin{array}{l}\text { Endoplasmic } \\
\text { reticulum }\end{array}$ \\
\hline 43. & Q9Z979 & $\begin{array}{l}\text { Cytochrome D ubiquinol oxidase, } \\
\text { subunit I }\end{array}$ & 448 & Unknown & 8.93 & 50,674 & $\begin{array}{l}\text { Endoplasmic } \\
\text { reticulum }\end{array}$ \\
\hline 44. & Q9Z6M5 & Putative outer membrane protein & 262 & Unknown & 5.39 & 30,001 & $\begin{array}{l}\text { Endoplasmic } \\
\text { reticulum }\end{array}$ \\
\hline 45. & Q9K1U7 & Uncharacterized protein & 366 & Unknown & 9.4 & 40,828 & $\begin{array}{l}\text { Endoplasmic } \\
\text { reticulum }\end{array}$ \\
\hline
\end{tabular}


Table 1 (continued).

\begin{tabular}{|c|c|c|c|c|c|c|c|}
\hline $\begin{array}{l}\text { S. } \\
\text { No. }\end{array}$ & $\begin{array}{l}\text { Accession } \\
\text { No. }\end{array}$ & Proteins/Enzymes name & $\begin{array}{l}\text { No. of } \\
\text { Amino } \\
\text { acid }\end{array}$ & Function in bacteria & $\begin{array}{l}\text { pI } \\
\text { Values }\end{array}$ & $\begin{array}{l}\text { Mol. } \\
\text { Wt. }\end{array}$ & $\begin{array}{l}\text { Localization } \\
\text { by Hum- } \\
\text { mPLoc } 2.0\end{array}$ \\
\hline 46. & Q9Z8B6 & $\begin{array}{l}\text { Probable } \mathrm{Na}(+) \text {-translocating } \mathrm{NADH}- \\
\text { quinone reductase subunit } \mathrm{B}\end{array}$ & 503 & $\begin{array}{l}\text { Oxidoreductase, Ion transport, } \\
\text { Sodium transport, Transport }\end{array}$ & 9.02 & 55,280 & $\begin{array}{l}\text { Endoplasmic } \\
\text { reticulum }\end{array}$ \\
\hline 47. & Q9Z6U3 & Lipid-A-disaccharide synthase & 604 & $\begin{array}{l}\text { Glycosyltransferase, Transferase, } \\
\text { Lipid A biosynthesis }\end{array}$ & 9.29 & 69,014 & $\begin{array}{l}\text { Endoplasmic } \\
\text { reticulum }\end{array}$ \\
\hline 48. & Q9Z7D6 & Uncharacterized protein & 264 & Unknown & 8.4 & 31,052 & $\begin{array}{l}\text { Endoplasmic } \\
\text { reticulum }\end{array}$ \\
\hline
\end{tabular}

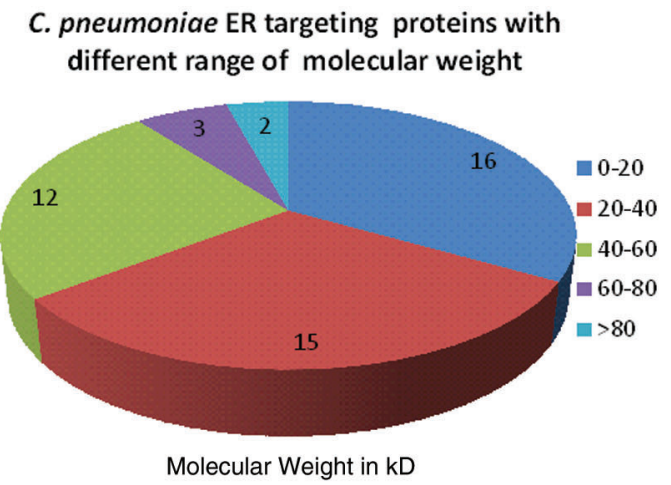

A

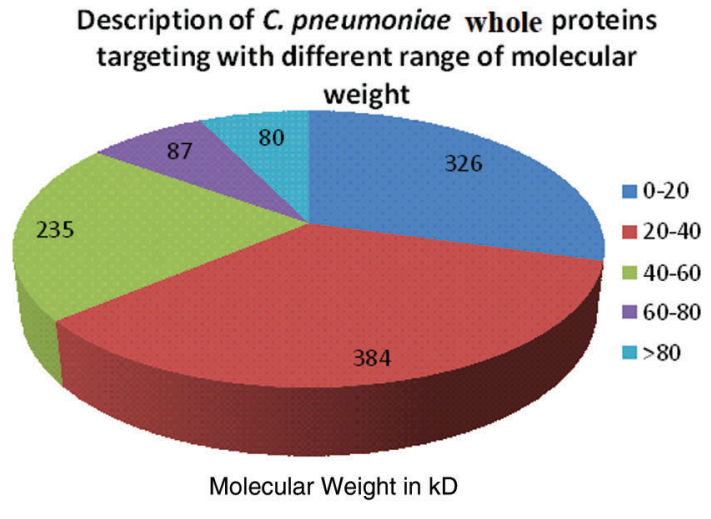

$\mathrm{B}$

FIGURE 2. Protein targeting blueprint. (A) Graph showed the protein targeting of C. pneumonia in endoplasmic reticulum of host cells with respect to various ranges of molecular weight. (B) Graph showed the protein targeting of C. pneumonia whole protein in endoplasmic reticulum of host cells with respect to various ranges of molecular weight.

\section{C. pneumoniae ER targeting proteins with different range of $\mathrm{pl}$ Value}

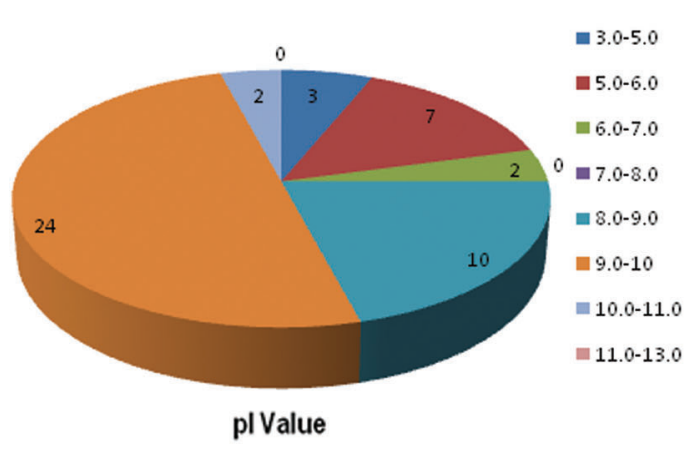

A

\section{Description of protein targeting in whole proteins of $C$. pneumoniae with different range of $\mathrm{pl}$ value}

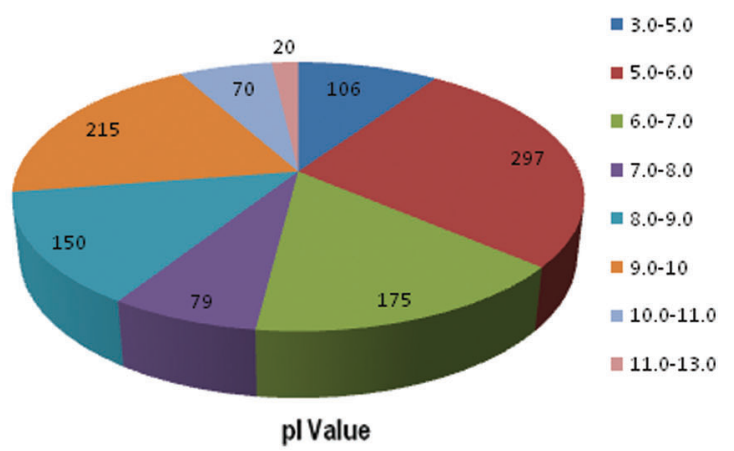

B

FIGURE 3. Protein targeting blueprint. (A) Graph showed the protein targeting of C. pneumonia in endoplasmic reticulum of host cells with respect to various ranges of pI value. (B) Graph showed the protein targeting of C. pneumonia whole protein in endoplasmic reticulum of host cells with respect to various ranges of $\mathrm{pI}$ value.

in the progression of various types of cancer (Khan et al., 2016; Khan et al., 2020; Khan et al., 2017). The proteins and enzymes that exist in the ER are known as ER-resident proteins. ERresident proteins are an important topic in ER-related studies. Several of the ER-resident proteins and enzymes have specific protein sorting signals including KDEL or KXXX, while some others proteins do not having such signals (Stornaiuolo et al., 2003). Information of proteins and enzymes localization in different subcellular location may be helpful to know the clues of different functions. It is prerequisite to reveal the information and functions of proteins/enzymes located in intricate pathways of different cell organelles.

Infections are considered as an important part of the natural path of cancer. Pneumonia is very common disease which influencing approximate 450 million persons every year and finding all over in the world (Biscevic-Tokic et al., 2013). Approximate $50 \%-70 \%$ patients has been showed lung cancer with pneumonia (Akinosoglou et al., 2013). It is 
a major reason of deaths with about $7 \%$ of total deaths worldwide every year (Ruuskanen et al., 2011). The cases of lung cancer and pneumonia enhanced noticeably (Shen et al., 2016). The molecular mechanism of association of C. pneumoniae with lung cancer is poorly investigated till date. We were predicted targeting of various enzymes and proteins in ER of human cell which includes Glycogen synthase (Accession No. Q9Z6V8), Glucose-6-phosphate 1dehydrogenase (G6PD) (Accession No. Q9Z8U6), ABC transporter (Accession No. Q7VPR2), Phosphatidylserine decarboxylase proenzyme (Accession No. Q9Z767), Lipoprotein signal peptidase (Accession No. Q9Z817), Glycogen phosphorylase (Accession No. Q9Z8N1), Lipid-Adisaccharide synthase (Accession No. Q9Z6U3). Although in current study we have deciphered the 48 proteins to target in ER but the functions of various proteins still unknown. The targeted enzymes and proteins may change the normal functioning of protein folding in ER of during infection and help in the growth of lung cancer. Accumulation of C. pneumoniae unfolded enzymes and proteins in the human ER possible act as a factor of ER stress and promote the cleavage of ATF6, which consequently facilitates the activation of unfolded protein response (UPR). The UPR activation has associated with the progression of cancer and lung diseases (Barabutis, 2020; Piton et al., 2016; Wang et al., 2014). It have reported that the expression of G6PD is enhanced in various tumors such as colon cancers, leukemia, gastrointestinal cancers, breast cancers, endometrial carcinomas, liver cancer and lung cancer (Batetta et al., 1999; Jiang et al., 2013; Rao et al., 1997; van Driel et al., 1999).

The functions and other informations of the ER targeted proteins of C. pneumoniae were showed in Tab. 1. Hence, an important basic purpose in proteomics and molecular cell biology is to decipher the subcellular targeting of proteins and enzymes in the whole cell. It is also very essential for prioritizing and selecting the accurate goals for drug development. Unfortunately, both processes are time consuming, laborious with and high expenses. To confirm the subcellular location of proteins and enzymes in various organelles of cell is completely based on laboratory works.

The cells constantly translate the great variety of proteins and enzymes. The translated proteins need to be folded correctly, post-translationally modification, accumulated into complexes and located to their ultimate destinations of subcellular organelle. If some mistakes arise in the maturation process the normal functioning of the cell disturbed. In the current study we are focused to decipher the protein targeting of $C$. pneumoniae in endoplasmic reticulum of host cell.

With the availability of next generation sequences data of proteins sequences, we needed highly desired in silico approaches for rapidly and efficiently identifying the subcellular locations of uncharacterized proteins based on their sequence information alone. ER is the main site of protein modification and protein folding. Misfolded proteins are responsible to stimulates the UPR in the ER (Schmidt et al., 2019), which increases the phenomena of protein folding to restore homeostasis (Choi and Song, 2020). UPR dysregulation signalling contributes to the pathogenesis during infection. The ER stress is related to pathogenesis of different diseases, including diabetes, neurodegenerative disorders, cancer, etc. Nevertheless, the pathogen proteins which have targeted in ER may disturbed the homeostasis and responsible for alteration in normal functioning of host cells. These changes may connect with the abnormal growth of infected cells and act as a prominent factor of cancer growth.

\section{Conclusion}

The ER is responsible for various housekeeping functions in the cell and act as a key organelle for the final maturation of proteins that controls its homeostasis state. Change in homeostasis has been associated with the progression of various situations including cancer, which is the highly challenging problem in the present time. The C. pneumoniae bacterial protein targeting in ER of human lung cells may disturbed the normal functioning of ER and act as a potential factor for the growth of lung cancer. Alterations in the UPR connected with the growth and development of cancer due to accumulation of pathogen proteins. In the present study we deciphered the C. pneumoniae protein targeting in ER and their association with lung cancer. We observed that the intercellular infection of C. pneumoniae in human cells acts as an etiological factor in lung cancer. Therefore, our novel finding provides the new direction to researchers, scientists and clinicians for the management and treatment of C. pneumonia associated lung cancer.

Acknowledgement: The authors extend their appreciation to the College of Applied Medical Sciences Research Center and the Deanship of Scientific Research, King Saud University, Riyadh, Saudi Arabia for their kind support.

Availability of Data and Materials: All data generated or analyzed during this study are included in this published article.

Authors' Contributions: YL and AAC separately assessed electronic search, eligibility of the studies, inclusion criteria; HAS and AM design the idea, help in manuscript drafting; SK and AS supervised the whole study including formulation of research idea, literature review, data collection, manuscript drafting with critical revision in final draft of manuscript.

Funding Statement: This research was funded by the Deanship of Scientific Research at Princess Nourah bint Abdulrahman University through the Fast-track Research Funding Program.

Conflicts of Interest: The authors declare that they have no conflicts of interest to report regarding the present study.

\section{References}

Airenne S, Surcel HM, Tuukkanen J, Leinonen M, Saikku P (2002). Chlamydia pneumoniae inhibits apoptosis in human epithelial and monocyte cell lines. Scandinavian Journal of Immunology 55: 390-398.

Akinosoglou KS, Karkoulias K, Marangos M (2013). Infectious complications in patients with lung cancer. European Review for Medical and Pharmacological Sciences 17: 8-18.

Arthur JC, Perez-Chanona E, Muhlbauer M, Tomkovich S, Uronis JM et al. (2012). Intestinal inflammation targets cancer-inducing activity of the microbiota. Science 338: 120-123. 
Barabutis N (2020). Unfolded protein response in lung health and disease. Frontiers in Medicine 7: 344.

Batetta B, Pulisci D, Bonatesta RR, Sanna F, Piras S et al. (1999). G6PD activity and gene expression in leukemic cells from G6PD-deficient subjects. Cancer Letters 140: 53-58.

Biscevic-Tokic J, Tokic N, Musanovic A (2013). Pneumonia as the most common lower respiratory tract infection. Medical Archives 67: 442-445.

Braakman I, Bulleid NJ (2011). Protein folding and modification in the mammalian endoplasmic reticulum. Annual Review of Biochemistry 80: 71-99.

Bray F, Ferlay J, Soerjomataram I, Siegel RL, Torre LA, Jemal A (2018). Global cancer statistics 2018: GLOBOCAN estimates of incidence and mortality worldwide for 36 cancers in 185 countries. CA: A Cancer Journal for Clinicians 68: 394-424.

Chaturvedi AK, Gaydos CA, Agreda P, Holden JP, Chatterjee N et al. (2010). Chlamydia pneumoniae infection and risk for lung cancer. Cancer Epidemiology and Prevention Biomarkers 19: 1498-1505.

Choi JA, Song CH (2020). Insights into the role of endoplasmic reticulum stress in infectious diseases. Frontiers in Immunology 10: 3147.

Ferlay J, Soerjomataram I, Dikshit R, Eser S, Mathers C, Rebelo M, Parkin DM, Forman D, Bray F (2015) Cancer incidence and mortality worldwide: Sources methods and major patterns in GLOBOCAN 2012. International Journal of Cancer 136: E359-E386.

Fischer SF, Schwarz C, Vier J, Hacker G (2001). Characterization of antiapoptotic activities of Chlamydia pneumoniae in human cells. Infection \& Immunity 69: 7121-7129.

Giles DK, Wyrick PB (2008). Trafficking of chlamydial antigens to the endoplasmic reticulum of infected epithelial cells. Microbes and Infection 10: 1494-1503.

Hetz C, Chevet E, Oakes SA (2015). Proteostasis control by the unfolded protein response. Nature Cell Biology 17: 829-838.

Hua-Feng X, Yue-Ming W, Hong L, Junyi D (2015). A meta-analysis of the association between Chlamydia pneumoniae infection and lung cancer risk. Indian Journal of Cancer 52: e112-e115.

Jiang P, Du W, Yang X (2013). A critical role of glucose-6-phosphate dehydrogenase in TAp73-mediated cell proliferation. Cell Cycle 12: 3720-3726.

Kalman S, Mitchell W, Marathe R, Lammel C, Fan J et al. (1999). Comparative genomes of Chlamydia pneumoniae and C. trachomatis. Nature Genetics 21: 385-389.

Khan S (2015). Potential role of Escherichia coli DNA mismatch repair proteins in colon cancer. Critical Reviews in Oncology/Hematology 96: 475-482.

Khan S, Imran A, Khan AA, Abul Kalam M, Alshamsan A (2016). Systems biology approaches for the prediction of possible role of Chlamydia pneumoniae proteins in the etiology of lung cancer. PLoS One 11: e0148530.

Khan S, Zaidi S, Alouffi AS, Hassan I, Imran A, Khan RA (2020). Computational proteome-wide study for the prediction of Escherichia coli protein targeting in host cell organelles and their implication in development of colon cancer. ACS Omega 5: 7254-7261.

Khan S, Zakariah M, Rolfo C, Robrecht L, Palaniappan S (2017). Prediction of mycoplasma hominis proteins targeting in mitochondria and cytoplasm of host cells and their implication in prostate cancer etiology. Oncotarget 8: 30830-30843.

Koyi H, Branden E, Gnarpe J, Gnarpe H, Arnholm B, Hillerdal G (1999). Chlamydia pneumoniae may be associated with lung cancer. Preliminary Report on a Seroepidemiological Study. Apmis 107: 828-832.

Littman AJ, Jackson LA, Vaughan TL (2005). Chlamydia pneumoniae and lung cancer: Epidemiologic evidence. Cancer Epidemiology and Prevention Biomarkers 14: 773-778.

Magat EM, Balanag GA, Carino AM, Fellizar A, Ortin TS et al. (2020). Clostridioides difficile antibody response of colorectal cancer patients versus clinically healthy individuals. Bioscience of Microbiota, Food and Health 39: 123-127.

Myers GS, Mathews SA, Eppinger M, Mitchell C, O'brien KK et al. (2009). Evidence that human Chlamydia pneumoniae was zoonotically acquired. Journal of Bacteriology 191: 7225-7233.

Piton N, Wason J, Colasse E, Cornic M, Lemoine F et al. (2016). Endoplasmic reticulum stress, unfolded protein response and development of colon adenocarcinoma. Virchows Archiv 469: 145-154.

Rao KN, Elm MS, Kelly RH, Chandar N, Brady EP et al. (1997). Hepatic hyperplasia and cancer in rats: Metabolic alterations associated with cell growth. Gastroenterology 113: 238-248.

Read TD, Brunham RC, Shen C, Gill SR, Heidelberg JF et al. (2000). Genome sequences of Chlamydia trachomatis MoPn and Chlamydia pneumoniae AR39. Nucleic Acids Research 28: 1397-1406.

Ruuskanen O, Lahti E, Jennings LC, Murdoch DR (2011). Viral pneumonia. Lancet 377: 1264-1275.

Schmidt RM, Schessner JP, Borner GH, Schuck S (2019). The proteasome biogenesis regulator Rpn 4 cooperates with the unfolded protein response to promote ER stress resistance. eLife 8: e43244.

Schwarz DS, Blower MD (2016). The endoplasmic reticulum: Structure, function and response to cellular signaling. Cellular and Molecular Life Sciences 73: 79-94.

Sessa R, Di Pietro M, Schiavoni G, Macone A, Maras B et al. (2009). Chlamydia pneumoniae induces $\mathrm{T}$ cell apoptosis through glutathione redox imbalance and secretion of TNF-alpha. International Journal of Immunopathology and Pharmacology 22: 659-668.

Shen HB, Chou KC (2009). A top-down approach to enhance the power of predicting human protein subcellular localization: Hum-mPLoc 2.0. Analytical Biochemistry 394: 269-274.

Shen Y, Tian Z, Lu D, Huang J, Zhang Z et al. (2016). Impact of pneumonia and lung cancer on mortality of women with hypertension. Scientific Reports 6: 20.

Shirai M, Hirakawa H, Kimoto M, Tabuchi M, Kishi F et al. (2000). Comparison of whole genome sequences of Chlamydia pneumoniae J138 from Japan and CWL029 from USA. Nucleic Acids Research 28: 2311-2314.

Smigielski L, Aguilar GB, Kwaaitaal M, Zhang WJ, ThordalChristensen H (2019). The isoelectric point of proteins influences their translocation to the extrahaustorial matrix of the barley powdery mildew fungus. Cellular Microbiology 21: e13091.

Stornaiuolo M, Lotti LV, Borgese N, Torrisi MR, Mottola G et al. (2003). KDEL and KKXX retrieval signals appended to the same reporter protein determine different trafficking between endoplasmic reticulum, intermediate compartment, and Golgi complex. Molecular Biology of the Cell 14: 889-902.

van Driel BE, Valet GK, Lyon H, Hansen U, Song JY, Van Noorden CJ (1999). Prognostic estimation of survival of colorectal cancer patients with the quantitative histochemical assay of G6PDH activity and the multiparameter classification program CLASSIF1. Cytometry 38: 176-183. 
von Hertzen LC (1998). Chlamydia pneumoniae and its role in chronic obstructive pulmonary disease. Annals of Medicine 30: 27-37.

Wahl C, Maier S, Marre R, Essig A (2003). Chlamydia pneumoniae induces the expression of inhibitor of apoptosis 2 (c-IAP2) in a human monocytic cell line by an NF-kappaBdependent pathway. International Journal of Medical Microbiology 293: 377-381.
Wang WA, Groenendyk J, Michalak M (2014). Endoplasmic reticulum stress associated responses in cancer. Biochimica et Biophysica Acta 1843: 2143-2149.

Xiong WM, Xu QP, Xiao RD, Hu ZJ, Cai L, He F (2019). Genomewide DNA methylation and RNA expression profiles identified RIPK3 as a differentially methylated gene in Chlamydia pneumoniae infection lung carcinoma patients in China. Cancer Management Research 11: 5785-5797. 